\title{
Topical Anesthetic Misuse in Patients Admitted to Sabzevar Eye Clinic in Iran
}

\author{
Ebrahim Shirzadeh ${ }^{1}$, Nematullah Shomoossi², Hasan Abdolahzadeh ${ }^{2}$ \\ ${ }^{1}$ Department of Ophthalmology, School of Medicine, Sabzevar University of Medical Sciences, Sabzevar, Iran \\ ${ }^{2}$ School of Medicine, Sabzevar University of Medical Sciences, Sabzevar, Iran
}

\section{SUMMARY}

Topical anesthetic eye drops are used extensively for ophthalmic examinations but selftreatment and non-technical removal of foreign bodies using tetracaine drops can be hazardous. The present study intended to determine the inadmissible uses of anesthetic tetracaine eye drops, manner of drug obtaining and likelihood of the ocular complications in the patients.

This cross-sectional study was conducted on 162 patients with ocular pain and foreign body sensation, red eye or lid edema admitted to the Eye clinic in Sabzevar, Iran. Variables included age, sex, chief compliant, job, site of foreign bodies, diagnosis of problem, use of tetracaine drops, drug provision, times patients referred to the eye clinic, and kinds of treatment.

The most common chief complaint for admission to the Eye clinic was lacrimation $(55.6 \%)$, followed by ocular pain, and foreign body sensation (35.8\%). Some patients (30.9\%) (mostly welders) inadmissibly used topical tetracaine eye drops; $21.6 \%$ of cases obtained tetracaine eye drops from drugstores without doctor's prescription, and only $3.7 \%$ provided drugs by prescription. Corneal site $(81.5 \%)$ was the most common location of foreign body; metallic foreign body $(63 \%)$ was the most common. One patient was admitted in hospital for management.

Topical inadmissible tetracaine $(0.5 \%)$ is commonly used by welders, who obtain it from drugstores without prescriptions due to its simple usage and short acting pain relief. Supervision is required over drugstores for denying it if demanded without a prescription. Enhancing clients' awareness is also suggested.

Key words: tetracaine, drug misuse, foreign body, eye drop

Corresponding author:

Nematullah Shomoossi

E-mail: nshomoossi@yahoo.com 


\section{INTRODUCTION}

Various drugs may be available to lay people for potential use and misuse, and the number of victims misusing them is on the rise. Erroneous cultural and socioeconomic attitudes as well as the easy accessibility of over-the-counter drugs play an important role in the acceptance of these substances (1). Topical anesthetic eye drops are mostly used in the emergency departments and they provide superb analgesia to the painful eyes; they are also applied for ocular urgency without routine prescriptions $(2,3)$. Superficial ocular foreign bodies take victims to drugstores upon ophthalmic urgencies, where they conveniently find these eye drops appropriate for eliminating ocular pain, foreign body sensation and relief of ocular discomfort.

In a major town like Sabzevar in the northeastern part of Iran, the most common topical anesthetic eye drop used is tetracaine (i.e. anisthocain 0.50\% Sina Daru Co, Iran). Most patients tend to misuse it either after ultra-violate keratitis (UVK) or for corneal foreign body removal $(4,5)$. Self-treatment and non-technical removal of ocular foreign bodies by the help of anesthetic tetracaine eye drops can be a hazardous procedure particularly when they are used by lay people (6-8). Clinical evidence reveals that unauthorized uses of this ophthalmic drop by workers like welders, turners, blacksmiths, aluminum makers, and similar occupations are common; therefore, the aim of the present study was to determine the conditions of inadmissible uses of anesthetic tetracaine eye drop, application of the drug, site of ocular foreign bodies and likelihood of the ocular complications in patients seeking medical advice from a physician for eye discomfort.

\section{PATIENTS AND METHODS}

This clinically-based and cross-sectional study was conducted on 162 patients admitted to the ophthalmological clinic for eye discomforts. The study population included all patients admitted with the chief complaints of ocular pain and foreign body sensation, lacrimation, red eye or lid edema in Sabzevar Eye Clinic in Sabzevar, Iran. The study was performed from July 2014 to September 2014. Data collection was achieved by the eye examination as well as filling out a questionnaire. Variables consisted of age, sex, chief compliant, job, site of foreign bodies, diagnosis of the problem, use of tetracaine eye drops, manner of providing tetracaine eye drops, times patients were referred to the eye clinic, and kinds of treatment. Patient management consisted of foreign body removal and medication, mere medication, and hospitalization if required. The variables were categorized as follows: Yes-No for using tetracaine eye drops, if the patient's response was Yes, then the manner of drug providing was categorized as follows: from drugstore, by prescription, and other. Also, the duration of discomfort and times of patients admitted for medical consultation were enquired and determined by their related variables. There were no limitations for this study and the informed consent was obtained from all patients. Statistical analyses were performed using STATA for windows software (version 11). Descriptive and analytic statistics were used for data analysis.

\section{RESULTS}

Of 162 examined patients, $86.4 \%$ were male and $13.6 \%$ were female. Their mean age was $30.89 \pm 12.95$ years with a range of 1 to 70 years old. Distribution of patients by demographic data is presented in Table 1 . The results showed a significant relationship between gender and occupation with the use of tetracaine eye drops $(\mathrm{p}<0.001)$. The most common chief complaint was observed to be ocular lacrimation $(55.6 \%)$ and then ocular pain and foreign body (FB) sensation (35.8\%).

The frequency of patients admitted to the clinic due to their ocular symptoms is displayed in Table 2. The study revealed the rate of inadmissible use of tetracaine eye drops to be $30.9 \%$; also, the manner of drug provision from a drugstore without prescription was $21.6 \%$. Table 3 displays the distribution of patients' affected eye, anatomical site and type of the FB. Corneal FB with $81.5 \%$ (132) was the common site and metallic FB with $63 \%$ (102) was the most common type. Distribution of patients by duration of exposure to the ocular FB and admission to the eye clinic are displayed in Table 4. As Table 4 indicates, around $68 \%$ of the patients with FB referred to the eye clinic three days after the exposure and the lowest rate of admission $(20 \%)$ was on the first day of the exposure. Furthermore, the present study revealed that $13.6 \%$ of patients underwent ocular FB removal by unauthorized and non-medical people, distribution of which is shown in Table 5. Also, the study revealed that about $1.2 \%$ (2) of the patients used diclofenac eye drops (Sina Daru Co, Iran) for their pain control. 


\section{DISCUSSION}

The present study was designed to investigate the inadmissible uses of anesthetic tetracaine eye drop, application of the drug, site of ocular foreign bodies and likelihood of the ocular complications in patients seeking medical advice and treatment in Sabzevar Eye Clinic in Iran. As Table 1 indicates, the prevalence of eye disorders is higher in men $(86.4 \%)$ than in women, which shows the effect of masculine occupations with higher risks of ocular FB. Also, the most frequent age affected by FB was 25-59 years of age, while the least frequent age was among the elderly (older than 60). The most frequent FB cases had lower education which enhances the likelihood of their being unaware of security at workplaces, where about $46 \%$ of the cases were involved in metal working; this may highlight the need for wearing personal protective equipment (PPE) as well as training health and safety executive (HSE) rules for workers with lower education; this may require responsibilities for employers, too. In addition, about $54 \%$ of the cases were involved in non-metal works, which further stresses the need for public education about the safety and security in the workplace.

Topical ocular anesthetic eye drops abuse can lead to superficial punctuate keratitis, persistent corneal epithelial defects, stromal/ring infiltrates, corneal edema, endothelial damage and ocular inflammation (2). It is thought that preservatives in anesthetics may play a further role in toxicity (9). Symptoms of such patients included photophobia, ocular pain FB sensation, red eye,

Table 1: Distribution of patients by demographic variables

\begin{tabular}{|c|c|c|c|c|}
\hline Variable & $\begin{array}{c}\text { Use tetracaine } \\
\mathrm{N}(\%)\end{array}$ & $\begin{array}{c}\text { Not using } \\
\text { tetracaine N }(\%)\end{array}$ & $p$-value & Total \\
\hline \multicolumn{5}{|c|}{ Sex } \\
\hline Male & $50(35.7)$ & $90(64.2)$ & \multirow{2}{*}{0.000} & $86.4)(140$ \\
\hline Female & $22(100)$ & $0(0)$ & & 13.5)(22 \\
\hline \multicolumn{5}{|c|}{ Age } \\
\hline Childhood (1-10) & 0 & $11(100)$ & \multirow{4}{*}{0.2} & $11(6.79)$ \\
\hline $\begin{array}{c}\text { Adolescence } \\
(11-25)\end{array}$ & $16(40)$ & $24(60)$ & & $40(24.6)$ \\
\hline $\begin{array}{l}\text { Middle age } \\
(26-59)\end{array}$ & $32(29.3)$ & $77(70.6)$ & & $109(67.2)$ \\
\hline Old age $(>60)$ & 2 & 0 & & $2(1.2)$ \\
\hline \multicolumn{5}{|c|}{ Education } \\
\hline Illiterate & $6(30)$ & $14(70)$ & \multirow{3}{*}{0.9} & $20(12.3)$ \\
\hline Diploma< & $40(31.25)$ & $88(68.7)$ & & $128(79.01)$ \\
\hline Academic & $4(28.5)$ & $10(71.4)$ & & $14(8.64)$ \\
\hline \multicolumn{5}{|c|}{ Occupation } \\
\hline Welder & 22(51.1) & $21(48.8)$ & \multirow{8}{*}{0.000} & $43(26.5)$ \\
\hline Blacksmith & $3(75)$ & $1(25)$ & & $4(2.4)$ \\
\hline Turner & $10(35.7)$ & $18(64.2)$ & & $28(17.28)$ \\
\hline Worker & $4(30.77)$ & $9(69.23)$ & & $13(8.02)$ \\
\hline Aluminum maker & $1(25)$ & $3(75)$ & & $4(2.47)$ \\
\hline Mechanic & $4(66.67)$ & $2(33.33)$ & & $6(3.70)$ \\
\hline Shepherd & $0(0)$ & $3(100)$ & & $3(1.85)$ \\
\hline Other & $6(9.84)$ & $55(90.16)$ & & $61(37.6)$ \\
\hline
\end{tabular}


Table 2: Distribution of patients by ocular symptoms and tetracaine eye drops misuse and their providing

\begin{tabular}{ccc}
\hline \hline Variable & Frequency & Percent \\
\hline Lacrimation & 90 & 55.6 \\
\hline $\begin{array}{c}\text { Foreign body } \\
\text { sensation and } \\
\text { pain }\end{array}$ & 58 & 35.8 \\
\hline Red eye & 8 & 4.9 \\
\hline Inflamed eye & 6 & 3.7 \\
\hline Total & 162 & 100.0 \\
\hline Use of tetracaine eye drop & \\
\hline Yes & 50 & 30.9 \\
\hline No & 112 & 69.1 \\
\hline Tetracaine provide \\
\hline Drugstore & 35 & 21.6 \\
\hline Physician & 6 & 3.7 \\
\hline Other & 10 & 6.2 \\
\hline No provide & 111 & 68.5 \\
\hline \hline
\end{tabular}

decreased vision and tearing (4). Because of concerns for delayed healing and corneal erosion (2), corneal keratitis secondary to the misuse of tetracaine eye drops may initially be treated for acanthamoeba keratitis since topical ocular anesthetic drops abuse may appear misdiagnosed as acanthamoeba keratitis (9).

In the present study, the most common chief complaint was observed to be ocular lacrimation (55.6\%), and then ocular pain and FB sensation (35.8\%). The results of this study showed that $30.9 \%$ of patients inadmissibly used topical tetracaine eye drops; also, $21.6 \%$ of cases provided tetracaine eye drops from drugstores without doctor's prescription, and only $3.7 \%$ provided drugs by prescription. As indicated in Table 2, about $27.8 \%$ of the cases with $\mathrm{FB}$ in the eye were observed to have obtained drugs from non-experts, a really remarkable threat of self-treatment which requires public education and cultural change. This has occurred despite the contraindication of anesthetic eye drops (even by medical doctors) except in eye clinics for emergency medical cases including eye burns, measuring intraocular pressure and extracting eye foreign bodies. However, in the present study, 3.7\% of the cases obtained the eye drop by medical prescription; this may also be considered a non-scientific medical measure, requiring refresher courses for GPs to re-emphasize its use in emergency cases.

Similarly, Sharifi and colleagues studied the prevalence of topical ocular anesthetic abuse among welders in Iran; they found that from 390 welders included in the study, a total of 314 welders $(80.5 \%)$ had used topical anesthetics at least once during their career (10). Almost $90 \%$ of them stated a preference for selftreatment over seeking help from a physician due to cultural and financial reasons; also, the most commonly used topical anesthetic was tetracaine; most of the subjects $(97.4 \%)$ had obtained the drugs from pharmacies without a prescription (10). In another study by Erdem and coworkers, the misuse of topical anesthetic eye drops abuse was shown from 12 eyes of 8 patients who were evaluated retrospectively, and one of the patients provided the drug with a primary care practitioner's prescription, but for the other 7 patients, it was available from pharmacies without prescription (11). Also, Katsimpris and coworkers described the clinical findings in five patients with topical anesthetic abuse with a detailed history in all patients; it was revealed that topical anesthetic abuse led to keratitis by obtaining anesthetic drops from the pharmacy without medical prescription (12). However, in the present study, $21.6 \%$ of all patients with different occupations provided the drug from drugstores without doctor's prescription, and only $3.7 \%$ provided drugs by physician's prescription. Topical anesthetic drops easily provided from pharmacies can be considered as an important alarm for topical anesthetic drug misuse and needs strict supervision over pharmacies. Pharmacists dispensing these drugs have a professional obligation that these products are being used appropriately and under the supervision of an ophthalmologist.

Unfortunately, these findings can be alarming signs of health problems in the target community we studied. Applicable to similar contexts, the causes of topical tetracaine abuse can be attributed to a number of factors including: (a) unawareness of patients from the side effects of topical anesthetics, (b) easy access to overthe-counter medical drugs, (c) low cost of drugs offered in drugstores, (d) prescription of the drug by nonspecialists, (e) idiosyncratically applied name of tetracaine as welder's drops, (f) recommendation of unauthorized people, and finally (g) removal of the foreign bodies from ocular surface by a bank note at the work place, since they think this form of foreign body removal is economically of low cost. As for the last option stated (i.e. the use of a bank note for easy removal), it can be infected and produce ocular re-infection particularly producing keratitis and conjunctivitis. Also, further 
Table 3: Distribution of patients by affected eye, anatomic site and type of foreign body

\begin{tabular}{|c|c|c|}
\hline Variable & Frequency & Percent \\
\hline \multicolumn{3}{|c|}{ Eye } \\
\hline $\mathrm{RE}$ & 83 & 51.2 \\
\hline LE & 76 & 46.9 \\
\hline Both Eye & 3 & 1.9 \\
\hline \multicolumn{3}{|c|}{ Anatomical site } \\
\hline Cornea & 132 & 81.5 \\
\hline Subpalpebral & 18 & 11.1 \\
\hline $\begin{array}{l}\text { Conjunctiva and } \\
\text { limbus }\end{array}$ & 12 & 7.4 \\
\hline \multicolumn{3}{|c|}{ Kind of FB } \\
\hline Metallic & 102 & 63 \\
\hline Woods & 20 & 12.3 \\
\hline Myiasis & 3 & 1.9 \\
\hline Corneal ulcer & 4 & 2.5 \\
\hline Rust material & 10 & 6.2 \\
\hline $\begin{array}{c}\text { Metallic FB and } \\
\text { ulcer }\end{array}$ & 1 & 0.6 \\
\hline Other & 22 & 13.6 \\
\hline
\end{tabular}

Table.4: Distribution of patients' approach times

\begin{tabular}{lcc}
\hline Variable & Frequency & Percent \\
\hline \multicolumn{3}{c}{ Approach times } \\
\hline One & 124 & 76.5 \\
\hline Two & 37 & 22.8 \\
\hline Three & 1 & 0.6 \\
\hline Time they referred to ophthalmologist \\
\hline One day & 20 & 12.3 \\
\hline Two days & 42 & 25.9 \\
\hline Three days & 48 & 29.6 \\
\hline 3 days $>$ & 52 & 32.1 \\
\hline Total & 162 & 100.0 \\
\hline \hline
\end{tabular}

corneal abrasion by the mechanical action and trauma of the bank note may follow; as topical tetracaine is a shortacting drug and their anesthetic effect is about 20 minutes (13), patients may like to use it as frequently as possible for pain relief and eye comfort.
Among the findings, no significant difference was observed between the left and right eye FB cases (Table 3). However, it was observed that about $81.5 \%$ of the cases had corneal damages due to the ease of exposure of this part of the eye; since corneal involvement can increase more severe symptoms and early effects on the patient's sight, the sufferers normally refer to eye clinics sooner than other sufferers. Also, as indicated in Table 3, about $63 \%$ of the cases had metal particles as FB, they are mostly expected to wear protective equipment while doing metal welding.

As Table 4 indicates, around $61.7 \%$ of the patients with eye discomfort referred to the eye clinic three days after the exposure, which shows that either they underestimated the severity of the injury or they might have experienced less severe symptoms or misuse of anesthetic eye drops. However, the low rate of admission on the first day of the exposure $(20 \%)$ is likely to indicate either their awareness of the severity of the issue or the severity of the injury symptoms or avoiding to use anesthetic eye drops. Also, most cases referring to the eye clinic were those with first time experience of ocular FB $(74.7 \%)$, which can be considered as an advantage in public awareness; however, it may be compared with others referring to non-experts and preferring selftreatment, which is scientifically damaging and harmful (Table 5). Among these, one patient required hospitalization for treatment.

Since topically applied anesthetics like tetracaine eye drops interfere with corneal epithelial metabolism and repair, they cannot be accordingly used for chronic pain relief. However, topical anesthetics can become drugs of misuse eventually leading to chronic pain syndromes and vision loss; therefore, these drugs

Table 5: Distribution of patients with the first person' management and method of removing eye FB

\begin{tabular}{|c|c|c|}
\hline Variable & Frequency & Percent \\
\hline \multicolumn{3}{|c|}{ First removal by } \\
\hline GP & 19 & 11.7 \\
\hline Ophthalmologist & 121 & 74.7 \\
\hline Other & 22 & 13.6 \\
\hline \multicolumn{3}{|c|}{ Management } \\
\hline $\begin{array}{l}\text { FB removal and } \\
\text { medication }\end{array}$ & 154 & 95.1 \\
\hline Only medication & 7 & 4.3 \\
\hline Admission & 1 & 0.6 \\
\hline
\end{tabular}


should not be dispensed to patients (8) since the consequences of this inadmissible use except unwanted complications cannot be anything else. Also, the prolonged use of topical anesthetic eye drops may cause corneal erosions, including slow corneal wound healing $(9,10)$. In the present study, corneal ulcer was found in $2.5 \%$ of the cases (4).

\section{CONCLUSIONS}

Topical anesthetic misuse is mostly common among welders; ease of access in providing them from drugstores without prescription, simple usage and short-acting effects in pain relief are important reasons for its inadmissible usage. Repeated use of these products or duration of use can result in serious ocular complications. Therefore, essential measures are expec-ted in enhancing the awareness of the clients through educational programs; consequently, these products must be used appropriately and only under the super-vision of ophthalmologists.

\section{References}

1. McLane NI, Carroll DM. Ocular manifestations of drug abuse. Surv Ophthalmol. 1986:30:298-313. https://doi.org/10.1016/0039-6257(86)90062-7

2. Swaminathan A, Otterness K, Milne K, Rezaie S. The Safety of Topical Anesthetics in the Treatment of Corneal Abrasions: A Review. J Emerg Med. 2015;49:810-5. https:/doi.org/10.1016/j.jemermed.2015.06.069

3. Puls HA, Cabrera D, Murad MH et al. Safety and Effectiveness of Topical Anesthetics in Corneal Abrasions: Systematic Review and Meta-Analysis. J Emerg Med. 2015;49:816-24. https:/doi.org/10.1016/j.jemermed.2015.02.051

4. Sedaghat $M$, Abrishami M. Neurotrophic corneal ulcer after topical tetracaine abuse: Manage-ment guidelines. Iranian Red Crescent Med J. 2011;2011:55-7.

5. Sharifi A, Mokhtari M, Esmaeili $\mathrm{HH}$ et al. Prevalence of Abuse of Ophtalmic Anesthetic Drops among Welders in Kerman City (2007). J Kerman UniverMed Sci. 2009; 16:174-81.
6. Pharmakakis N, Katsimpris J, Melachrinou M, Koliopoulos J. Corneal complications following abuse of topical anesthetics. Eur J Ophthal. 2002;12:373-8.

7. Rosenwasser GO, Holland S, Pflugfelder SC et al. Topical anesthetic abuse. Ophthalmology. 1990;97:967-72. https:/doi.org/10.1016/S0161-6420(90)32458-2

8. Henkes HE, Waubke TN. Keratitis from abuse of corneal anaesthetics. BrJ Ophthalmol. 1978;62:62.

https:/doi.org/10.1136/bjo.62.1.62

9. Patel M, Fraunfelder FW. Toxicity of topical ophthalmic anesthetics. Expert OpinDrug Metab Toxicol. 2013;9:983-8. https:/doi.org/10.1517/17425255.2013.794219

10. Sharifi A, Sharifi H, Karamouzian Met al. Topical ocular anesthetic abuse among Iranian welders: time for action. Middle East Afr JOphthalmol. 2013;20:336. https:/doi.org/10.4103/0974-9233.120023

11. Erdem E, Undar IH, Esen E et al. Topical 
anesthetic eye drops abuse: are we aware of the danger? CutanOcul Toxicol 2013;32:18993.

https:/doi.org/10.3109/15569527.2012.744758

12. Katsimpris J, Sarantoulakou M, Kordelou A et al. Clinical findings in patients with topical anaesthetic abuse keratitis: a report of five cases. Klin Monbl Augenheilkd. 2007;224:303-8.

https:/doi.org/10.1055/s-2007-962933

13. Ophthalmology Aao. Basic and Clinical Science Course section 2: fundamentals and principles of ophthalmology. San Francisco: American Academy of Ophthalmology; 2008. 


\title{
Nepravilna upotreba topikalnih anestetskih kapi za oči kod bolesnika primljenih na očnu kliniku u Sabzevaru u Iranu
}

\author{
Ebrahim Shirzadeh ${ }^{1}$, Nematullah Shomoossi², Hasan Abdolahzadeh ${ }^{2}$ \\ ${ }^{1}$ Departman za oftalmologiju, Medicinski fakultet, Univerzitet medicinskih nauka u Sabzevaru, \\ Sabzevar, Iran \\ ${ }^{2}$ Medicinski fakultet, Univerzitet medicinskih nauka u Sabzevaru, Sabzevar, Iran
}

\section{SAŽETAK}

Topikalne anestetske kapi za oči se često koriste kod oftalmoloških pregleda, dok samolečenje $\mathbf{i}$ nestručno ukljanjanje stranih tela pomoću kapi tetrakaina može biti opasno. Cilj ove studije bio je da prikaže nedozvoljenu upotrebu anestetskih tetrakain kapi za oči, način dobijanja leka i mogućnost nastanka komplikacija u oku kod ovih bolesnika.

Ova studija preseka je obuhvatila 162 bolesnika primljena na očnu kliniku u Sabzevaru u Iranu, koji su imali bol u očima, tegobe zbog prisustva stranog tela, crvenilo u očima ili otečenost kapka. Ispitivane varijable su bile starost, pol, glavna tegoba, mesto prisustva stranog tela, dijagnoza, upotreba tetrakain kapi, dobijanje leka, broj upućivanja bolesnika na kliniku i vrsta tretmana.

Najčešće tegobe zbog kojih su bolesnici primani na kliniku bile su suzne oči $(55.6 \%)$, stanje praćeno bolom u oku i tegobama zbog prisustva stranog tela $(35,8 \%)$. Određeni broj bolesnika (30.9\%) (uglavnom varioci) su samonicijativno koristili topikalne tetrakain kapi za oči; $21,6 \%$ bolesnika su u apotekama dobili kapi bez lekarskog recepta, a samo $3.7 \%$ je imalo recept. Rožnjača $(81,5 \%)$ je bila najčešća lokacija stranog tela, dok su metalna strana tela (63\%) bila najčešća. Jedan bolesnik je bio primljen zbog bolničkog lečenja.

Topikalni tetrakain $(0,5 \%)$ najčešće koriste varioci koji ove kapi uzimaju bez recepta zbog jednostavne upotrebe i brzog prestanka bola. Preporučuje se bolje informisanje bolesnika

Ključne reči: tetrakain, nepravilna upotreba leka, strano telo, kapi za oči 